\title{
INDIAN AUTOMOBILE MANUFACTURING INDUSTRY - A STUDY ON THE FINANCIAL PERFORMANCE
}

\author{
DR. RAVI VEERARAGHAVAN
}

Professor, Xavier Institute of Management \& Entrepreneurship, Chennai, India

\begin{abstract}
The Automobile industry in India plays a major role in driving economic growth and technological advancement. Automobile Manufacturing companies employ over 5 Million people directly and through Auto Ancillary companies. Auto Ancillary companies are dependent on Automobile Manufacturing companies. In this paper, a study has been done on the financial performance of 13 Automobile Manufacturing companies listed on the Stock Exchange for the financial year ended 31st March 2020. The analysis of the key financial indicators for profitability, liquidity, solvency and efficiency of these companies shows that many Automobile Manufacturing companies are not financially healthy. Only 23\% of the companies (3 out of 13 companies) are in a 'safe zone' as far as financial distress and bankruptcy are concerned. The Covid-19 impact may adversely impact the financial performance further in the following financial year. Government support may be needed to protect this sector.
\end{abstract}

KEYWORDS: Automobile Manufacturing Industry, Financial Analysis, Ratio Analysis, Z-score

Received: Mar 09, 2021; Accepted: Apr 01, 2021; Published: Apr 08, 2021; Paper Id: IJBMRJUN20213

\section{INTRODUCTION}

The Automobile industry in India plays a major role in driving economic growth and technological advancement. India is expected to emerge as the third-largest automotive market in the world in terms of volume by 2026 , followed by China and the USA [1]. The Indian Automotive Manufacturing industry produced over 26 Million vehicles, including Passenger Cars, Commercial Vehicles, Three Wheelers, Two Wheelers and Quadricycles in April-March 2020.The total production of vehicles includes the production of 21,036,294 Two-wheelers and 752,022 Commercial vehicles. India has also exported 47, 65,754 vehicles during the financial year 2019-20 [2]. The Automobile Industry has received an FDI Equity inflow of about USD 2.8 Billion for the financial year 2019-20 [3]. The annual revenue of the Indian Automobile Industry during the financial year 2018-19 was around USD 118 Billion, which is equivalent to 7.1\% of the country's total GDP, 27\% of Industrial GDP and 49\% of Manufacturing GDP [4]. Several policy measures have been taken by the Government of India and other stakeholders in the Indian market are aimed to make India a leader in the two-wheeler and four-wheeler market in the world.

The automotive industry can be segmented as (a) Automotive Manufacturers and (b) Auto Ancillaries. Auto Ancillaries are dependent on Automotive Manufacturers. Automotive Manufacturers include manufacturers of Two Wheelers, Three Wheelers, Passenger vehicles, Quadricycles, Commercial Vehicles and trucks and Tractors. This study relates to the analysis of the financial performance of the listed companies in the Auto Manufacturing Companies in India. The study does not include foreign companies that are not listed on the stock exchanges in India. 


\section{METHODOLOGY}

Financials available for the 13 Automobile manufacturing companies for the financial year 2019-20 have been considered for this study. It does not include Auto Ancillary companies. The study covers the identification of listed Automobile manufacturing companies in India, financial analysis of the annual financial statements of the 13 companies identified, computation of financial ratios, analysis of these ratios and the interpretation. This study analyses the key financial ratios relating to Profitability, Liquidity, Solvency and Efficiency. These ratios are explained below:

Profitability: Profit after tax/Sales for the year. It shows the profit earned as a percentage of the revenue and indicates the overall profitability of the business.

Operating Margin: Operating Profits/Sales for the year. Operating margin does not include income from investments, taxes and interest. It reflects the profitability of the core business operation.

Debtors Outstanding (No. of days): It indicates the value of debtors outstanding in terms of sales. The efficiency of debtor collections can be ascertained by working out this ratio.

Inventory Holding (No. of days): It reflects the relationship between the cost of goods sold during the year and the average stock kept during that year. It reflects the efficiency of the operation in managing stock level.

Creditors Outstanding (No. of days): It indicates the value of creditors outstanding in terms of the cost of goods sold. It shows the extent of the credit period obtained from Suppliers.

Assets Turnover Ratio: This ratio is used to measure how efficiently the assets are being deployed to generate revenue. Higher turnover would mean effective utilization of assets. On the other hand, a lower Assets Turnover ratio indicates that the business operation is not using full capacity.

Current Ratio: It reflects the value of Current Assets held against the value of Current Liabilities. The current ratio indicates the ability of the firm to meet its current obligations. If the current ratio is higher, it would mean that the business has greater short term liquidity.

Quick Ratio: Quick Ratio shows the ability of the business to meet its current liabilities. Inventory is not considered liquid for this purpose. A ratio of 1 considered ideal for short term liquidity.

Altman Z-Score: Altman Z-score [5] is used to predict the potential bankruptcy of a company. It is a measure developed by Prof. Edward Altman in 1968. It combines five financial ratios as below:

"Altman Z-Score $=1.2 \mathrm{~A}+1.4 \mathrm{~B}+3.3 \mathrm{C}+0.6 \mathrm{D}+1.0 \mathrm{E}$

A - Working Capital/Total Assets ratio

B - Retained Earnings/Total Assets ratio

C - Earnings before Interest and Taxes/Total Assets ratio

D - Market Value of Equity/Total Liabilities ratio

E - Total Sales/Total Assets ratio" 
Interpretation of the Z-Score: A score below 1.8 indicates that the enterprise is like to become bankrupt. Companies with Z-score above 3 are safe and unlikely to face bankruptcy. A score between 1.8 and 3 indicates that the company is in a gray area.

\section{ANALYSIS AND FINDINGS}

The 23 Auto Manufacturing companies analyzed are of different sizes in terms of revenue. The financial ratios worked out are analyzed by the revenue size in the following paragraphs.

Profile of the companies by revenue is given in Table 1

Table 1: Revenue Analysis

\begin{tabular}{|c|c|c|c|c|c|}
\hline Categories & $\begin{array}{c}\text { Annual Revenue } \\
\text { (INR in Crores) }\end{array}$ & \multicolumn{2}{|c|}{ Companies No. \% } & \multicolumn{2}{c|}{$\begin{array}{c}\text { Aggregate Revenue } \\
\text { (INRs in Crores) \% }\end{array}$} \\
\hline Large Companies & Above 50000 & 3 & $23 \%$ & 365561 & $77.5 \%$ \\
\hline Medium Companies & $10000-50000$ & 4 & $31 \%$ & 88358 & $18.8 \%$ \\
\hline Small Companies & $1000-10000$ & 3 & $23 \%$ & 16184 & $3.4 \%$ \\
\hline Very small Companies & Below 1000 & 3 & $23 \%$ & 1612 & $0.3 \%$ \\
\hline \multicolumn{2}{|r|}{ Total } & $\mathbf{1 3}$ & $\mathbf{1 0 0 \%}$ & $\mathbf{4 7 1 7 1 5}$ & $\mathbf{1 0 0 \%}$ \\
\hline
\end{tabular}

Table 2: Profitability Analysis

\begin{tabular}{|l|c|c|c|c|c|}
\hline \multirow{2}{*}{ Category } & \multirow{2}{*}{ Total } & \multicolumn{4}{|c|}{ Profitability (Profit after Tax/Revenue) } \\
\cline { 3 - 6 } & & Loss & $\mathbf{0 - 3 \%}$ & $\mathbf{3 \% - 6 \%}$ & Above 6\% \\
\hline Large Companies & 3 & 1 & 1 & 0 & 1 \\
\hline Medium Companies & 4 & 1 & 1 & 0 & 2 \\
\hline Small Companies & 3 & 1 & 0 & 0 & 2 \\
\hline Very Small Companies & 3 & 2 & 0 & 0 & 1 \\
\hline Total No of companies & $\mathbf{1 3}$ & $\mathbf{5}$ & $\mathbf{2}$ & $\mathbf{0}$ & $\mathbf{6}$ \\
\hline Total \% & $\mathbf{1 0 0 \%}$ & $\mathbf{3 9 \%}$ & $\mathbf{1 5 \%}$ & $\mathbf{0 \%}$ & $\mathbf{4 6 \%}$ \\
\hline
\end{tabular}

Table 3: Operating Margin Analysis

\begin{tabular}{|l|c|c|c|c|c|}
\hline \multirow{2}{*}{ Category } & \multirow{2}{*}{ Total } & \multicolumn{4}{c|}{ Operating Margin/Revenue) } \\
\cline { 4 - 6 } & & Loss & $\mathbf{0}-\mathbf{5 \%}$ & $\mathbf{5 \%}-\mathbf{1 0 \%}$ & Above 10\% \\
\hline Large Companies & 3 & & & 2 & 1 \\
\hline Medium Companies & 4 & & & & 4 \\
\hline Small Companies & 3 & & & 1 & 2 \\
\hline Very Small Companies & 3 & 1 & 1 & & 1 \\
\hline Total No of companies & $\mathbf{1 3}$ & $\mathbf{1}$ & $\mathbf{1}$ & $\mathbf{3}$ & $\mathbf{8}$ \\
\hline \multicolumn{1}{|c|}{ Total \% } & $\mathbf{1 0 0 \%}$ & $\mathbf{7 . 5 \%}$ & $\mathbf{7 . 5 \%}$ & $\mathbf{2 3 \%}$ & $\mathbf{6 2 \%}$ \\
\hline
\end{tabular}

Table 4: Debtors Outstanding (No of days Sales Outstanding)

\begin{tabular}{|l|c|c|c|c|c|}
\hline \multirow{2}{*}{ Category } & \multirow{2}{*}{ Total } & \multicolumn{4}{c|}{ No of days of Debtors Outstanding } \\
\cline { 3 - 6 } & & Up to $\mathbf{3 0}$ & $\mathbf{3 0}-\mathbf{4 5}$ & $\mathbf{4 5}-\mathbf{6 0}$ & $\mathbf{7 6 0}$ \\
\hline Large Companies & 3 & 3 & & & \\
\hline Medium Companies & 4 & 4 & & & \\
\hline Small Companies & 3 & 2 & & 1 & \\
\hline Very Small Companies & 3 & 1 & & 1 & 1 \\
\hline Total No of companies & $\mathbf{1 3}$ & $\mathbf{1 0}$ & $\mathbf{0}$ & $\mathbf{2}$ & $\mathbf{1}$ \\
\hline \multicolumn{1}{|c|}{ Total \% } & $\mathbf{1 0 0 \%}$ & $\mathbf{7 7 \%}$ & $\mathbf{0 \%}$ & $\mathbf{1 5 \%}$ & $\mathbf{8 \%}$ \\
\hline
\end{tabular}


Table 5: Inventory Holding (No. of days)

\begin{tabular}{|l|c|c|c|c|c|}
\hline \multirow{2}{*}{ Category } & \multirow{2}{*}{ Total } & \multicolumn{4}{c|}{ Inventory Holding (No of days) } \\
\cline { 3 - 6 } & & Up to $\mathbf{4 5}$ & $\mathbf{4 5}$ to $\mathbf{6 0}$ & $\mathbf{6 0}-\mathbf{9 0}$ & Above 90 \\
\hline Large Companies & 3 & 1 & & 2 & \\
\hline Medium Companies & 4 & 4 & & & \\
\hline Small Companies & 3 & 1 & & 1 & 1 \\
\hline Very Small Companies & 3 & 1 & & & 2 \\
\hline Total No of companies & $\mathbf{1 3}$ & $\mathbf{7}$ & $\mathbf{0}$ & 3 & $\mathbf{3}$ \\
\hline \multicolumn{1}{|c|}{ Total \% } & $\mathbf{1 0 0 \%}$ & $\mathbf{5 4 \%}$ & $\mathbf{0 \%}$ & $\mathbf{2 3 \%}$ & $\mathbf{2 3 \%}$ \\
\hline
\end{tabular}

Table 6: Creditors Outstanding (No. of days)

\begin{tabular}{|l|c|c|c|c|c|}
\hline \multirow{2}{*}{ Category } & \multirow{2}{*}{ Total } & \multicolumn{4}{|c|}{ Creditors Outstanding (No of days) } \\
\cline { 3 - 6 } & & Upto 30 & $\mathbf{3 0 - 4 5}$ & $\mathbf{4 5 - 6 0}$ & $\mathbf{6 0}$ \\
\hline Large Companies & 3 & & 1 & 1 & 1 \\
\hline Medium Companies & 4 & & & 3 & 1 \\
\hline Small Companies & 3 & & 1 & 1 & 1 \\
\hline Very Small Companies & 3 & 1 & 1 & 1 & \\
\hline Total No of companies & $\mathbf{1 3}$ & $\mathbf{1}$ & $\mathbf{3}$ & $\mathbf{6}$ & $\mathbf{3}$ \\
\hline \multicolumn{1}{|c|}{ Total \% } & $\mathbf{1 0 0 \%}$ & $\mathbf{8 \%}$ & $\mathbf{2 3 \%}$ & $\mathbf{4 6 \%}$ & $\mathbf{2 3 \%}$ \\
\hline
\end{tabular}

Table 7: Assets Turnover (No. of times)

\begin{tabular}{|l|c|c|c|c|}
\hline \multirow{2}{*}{ Category } & \multirow{2}{*}{ Total } & \multicolumn{3}{|c|}{ Turnover/Assets (No of times) } \\
\cline { 3 - 5 } & & Up to 1 & $\mathbf{1 ~ - 2}$ & Above 2 \\
\hline Large Companies & 3 & 1 & 2 & \\
\hline Medium Companies & 4 & 1 & 3 & \\
\hline Small Companies & 3 & 1 & 2 & \\
\hline Very Small Companies & 3 & 1 & & 2 \\
\hline Total No of companies & $\mathbf{1 3}$ & $\mathbf{4}$ & $\mathbf{7}$ & $\mathbf{2}$ \\
\hline \multicolumn{1}{|c|}{ Total \% } & $\mathbf{1 0 0 \%}$ & $\mathbf{3 1 \%}$ & $\mathbf{5 4 \%}$ & $\mathbf{1 5 \%}$ \\
\hline
\end{tabular}

Table 8: Current Ratio

\begin{tabular}{|l|c|c|c|c|}
\hline \multirow{2}{*}{ Category } & \multirow{2}{*}{ Total } & \multicolumn{3}{|c|}{ Current Assets/Current Liabilities } \\
\cline { 3 - 5 } & & Up to 2 & $\mathbf{2}$ to 3 & Above 3 \\
\hline Large Companies & 3 & 2 & 1 & 0 \\
\hline Medium Companies & 4 & 2 & 1 & 1 \\
\hline Small Companies & 3 & & 1 & 2 \\
\hline Very Small Companies & 3 & 1 & 1 & 1 \\
\hline Total No of companies & $\mathbf{9 4}$ & $\mathbf{5}$ & $\mathbf{4}$ & $\mathbf{4}$ \\
\hline \multicolumn{1}{|c|}{ Total \% } & $\mathbf{1 0 0 \%}$ & $\mathbf{3 8 \%}$ & $\mathbf{3 1 \%}$ & $\mathbf{3 1 \%}$ \\
\hline
\end{tabular}

Table 9: Quick Ratio

\begin{tabular}{|l|c|c|c|c|}
\hline \multirow{2}{*}{ Category } & \multirow{2}{*}{ Total } & \multicolumn{3}{|c|}{ Liquid Assets/Current Liabilities } \\
\cline { 3 - 5 } & & Up to 1 & $\mathbf{1}$ to 2 & Above 2 \\
\hline Large Companies & 3 & 2 & 1 & \\
\hline Medium Companies & 4 & 2 & 1 & 1 \\
\hline Small Companies & 3 & 1 & 1 & 1 \\
\hline Very Small Companies & 3 & 1 & 1 & 1 \\
\hline Total No of companies & $\mathbf{1 3}$ & $\mathbf{6}$ & $\mathbf{4}$ & $\mathbf{3}$ \\
\hline \multicolumn{1}{|c|}{ Total \% } & $\mathbf{1 0 0 \%}$ & $\mathbf{4 6 \%}$ & $\mathbf{3 1 \%}$ & $\mathbf{2 3 \%}$ \\
\hline
\end{tabular}


Table 10: Altman's Z-Score

\begin{tabular}{|l|c|c|c|c|}
\hline \multirow{2}{*}{ Category } & \multirow{2}{*}{ Total } & \multicolumn{3}{|c|}{ Altman's Z-Score } \\
\cline { 3 - 5 } & & Up to 1.8 & $\mathbf{1 . 8}$ to 3 & Above 3 \\
\hline Large Companies & 3 & 2 & 1 & \\
\hline Medium Companies & 4 & 2 & 1 & 1 \\
\hline Small Companies & 3 & 1 & 1 & 1 \\
\hline Very Small Companies & 3 & 1 & 1 & 1 \\
\hline Total No of companies & $\mathbf{1 3}$ & $\mathbf{6}$ & $\mathbf{4}$ & $\mathbf{3}$ \\
\hline Total \% & $\mathbf{1 0 0 \%}$ & $\mathbf{4 6 \%}$ & $\mathbf{3 1 \%}$ & $\mathbf{2 3 \%}$ \\
\hline
\end{tabular}

\section{KEY OBSERVATIONS}

The analysis of financial ratios worked out from the annual financials of automobile manufacturing companies reveals the following:

- Revenue: Nearly $78 \%$ of the total revenue came from 3 companies in the Automobile manufacturing sector considered in this study. The bottom 3 companies contribute only $0.34 \%$ of the total revenue (Table 1 ).

- Profitability: (i) The average Profit after tax on annual revenue for the financial year 2019-20 considering the total revenue of all the 13 companies is just $0.6 \%$. (ii) $54 \%$ of the auto companies made a profit of $3 \%$ or less. (iii) $39 \%$ of 13 companies ended the year with a loss. (iv) Even a large company incurred a loss during the financial year 2019-20. (Table 2)

- Operating Margin: (i) 38\% of the companies made an operating margin of less than 10\%. (3) The average Operating Margin of companies with revenue below INR $1000 \mathrm{Cr}$ is just $1.6 \%$, while the overall average Operating Margin of all the 13 companies is $10.4 \%$. (Table 3).

- Debtors Outstanding: (i) $77 \%$ of the companies manage the debtors outstanding within 30 days. (ii) $50 \%$ of small and very small companies have debtors' outstanding level over 45 days (Table 4).

- Inventory Holding: (i) 5 out of 7 medium and large companies manage inventory below 45 days' level. (ii) $2 / 3$ of the small and very small companies have inventory levels over 60 days (Table 5).

- Creditors Outstanding: (i) 6 out of 7 medium and large companies have creditors outstanding of 45 days and more. (ii) 2/3 of very small and small companies have creditors outstanding of over 45 days (Table 6).

- $\quad$ Assets Turnover Ratio: None of the small, medium \& large companies have Assets Turnover> 2 (Table 7).

- Current Ratio: (i) $38 \%$ of the companies are below 1. (ii) $69 \%$ of the companies are below 2 (Table 8). A current ratio of 2 is considered ideal for a comfortable financial position.

- Quick Ratio: $46 \%$ of the companies are below 1 (Table 9). A quick ratio below 1 indicates that the value of liquid assets is lower than current liabilities.

- Altman's Z-Score: Only 23\% of the companies (3 out of 13) are in the safe zone (Z-score above 3). 23\% of the companies, including a large company, are facing the risk of becoming bankrupt, as the Z-score is below 1.8 (3 out of 13). (Table 10). 


\section{LIMITATIONS}

The study does not include automotive manufacturing enterprises that are not listed on the Stock Exchange. A balance sheet is a snapshot of the financial position of an enterprise on the last day of the financial year and the value of assets and liabilities presented in financial statements may change or may even be manipulated [6]. The financial information relates to the financial year 2019-20, the impact of Covid 19 is not significant during this period.

\section{CONCLUSIONS}

The financial indicators for the level of Inventory and Creditors appear to be good, but the same may harm the auto ancillary companies that supply materials to auto manufacturing companies. The profitability, asset utilization and solvency parameters of the Auto Manufacturing Companies are not looking good. This would also impact the Auto Ancillary Manufacturers who supply materials to Automobile manufacturers. The new normal situation caused by Covid 19 during the subsequent year is going to have a major adverse impact on the auto industry. Considering the Automobile industry's (Auto manufacturing as well as Auto Ancillaries) contribution to the economy and employment, the Government may need to intervene and support the industry.

\section{REFERENCES}

1. https://www.mckinsey.com/industries/automotive-and-assembly/our-insights/the-future-of-mobility-in-indias-passengervehicle-market

2. Society of Indian Automobile Manufacturers, Automobile Production/Export Trends, www.siamindia.com

3. Factsheet on FDI - April 2000 to March 2020, Department for Promotion of Industry and Internal Trade https://dipp.gov.in/sites/default/files/FDI_Factsheet_March20_28May_2020.pdf

4. Nallusamy, S., et al. "Implementation of total productive maintenance to enhance the overall equipment effectiveness in medium scale industries." Int. J. Mech. Prod. Eng. Res. Dev 8 (2018): 1027-1038.

5. "Year Ender 2019 Ministry of Heavy Industry", Press Information Bureau, https://pib.gov.in/PressReleseDetailm.aspx?PRID=1597099

6. Saifuddin, Mohammad, Rahul Dhameja, and Aditya Shubham. "Analysing and Rectifying the Sluggish Movement of Gearbox in an Automobile Manufacturing Industry using Quality Assurance Tool." International Journal of Mechanical and Production Engineering Research and Development (IJMPERD) 8.4, Aug 2018, 179-188

7. Altman, Edward I. (September 1968). "Financial Ratios, Discriminant Analysis and the Prediction of Corporate Bankruptcy". Journal of Finance. 23 (4): 189-209 doi:10.1111/j.1540-6261.1968.tb00843.

8. Ayyakkannu, A. "Technical and soft skill competencies mapping at the entry level of diploma holders in mechanical and automobile engineering for auto and auto components industries." International Journal of Mechanical and Production Engineering Research and Development 8.1 (2018): 1209-1220.

9. “The Interpretation of Financial Statements in terms Of Contemporary Financial Analysis” published by Chief Assist. Prof. Krasimir Kulchev, PhD [2017] Business Management Book1, D A Tsenov Academy of Economics, Svishtov - p623

10. Pal, Shrabanti. "Evaluation of financial performance in terms of financial ratios-an empirical study on Indian automobile industry." International Journal of Business Management \& Research 5.3 (2015): 1-7. 